\title{
Failure prediction of road transportation firms: evidence from six European
} countries

\section{Predicción de la quiebra en empresas de transporte por carretera: evidencia a través de seis países europeos}

\author{
LUKASON, Oliver ${ }^{1} \dagger^{*} \&$ SALMAR, $\mathrm{Ott}^{2}$ \\ ${ }^{1,2}$ School of Economics and Business Administration, University of Tartu, Narva road 18, 51009 Tartu, Estonia \\ ID $1^{\text {st }}$ Author: Oliver, Lukason / ORC ID: 0000-0001-8135-1010, Researcher ID Thomson: G-9704-2019 \\ ID $1^{\text {st }}$ Co-author: Ott, Salmar
}

DOI: $10.35429 /$ EJM.2021.26.12.1.9

Received: January 01, 2021; Accepted: January 20, 2021

\begin{abstract}
This paper aims to create a failure prediction model for road transportation firms, as literature so far lacks intercountry evidence for this sector. Five financial ratios from Altman (1968) study are used for bankrupted and survived road transportation firms from six European countries with logistic regression as the method. The study indicates, that while all five financial ratios are significant in the intercountry prediction model, the accuracies of the model can vary through countries. The accuracies of single-country models do not differ a lot from the inter-country model accuracy, but in turn the significances of predictors can substantially vary through countries.
\end{abstract}

Road transportation firms, European countries, Failure prediction, Financial ratios

\begin{abstract}
Resumen
El objetivo de este articulo es crear un modelo de predicción de quiebra para las empresas de transporte por carretera, ya que hasta la fecha la revisión de la literatura muestra que no hay evidencia internacional para este sector. Se han utilizado cinco ratios financieros del estudio de Altman (1968) para empresas quebradas y sanas del sector transporte por carretera de seis países euroeos, siendo la regresion logística la metodología empleada. El estudio indica que, si bien los cinco ratios financieros son significativos en el modelo de predicción internacional, las precisiones del modelo pueden variar de un país a otro. Las precisiones de los modelos de un solo país no difieren mucho de la precisión del modelo internacional, pero a su vez la importancia de los predictores puede variar sustancialmente de un país a otro.
\end{abstract}

Empresas de transporte por carretera, Paises europeos, Predicción de quiebra, Ratios Financieros

Citation: LUKASON, Oliver, SALMAR, Ott. Failure prediction of road transportation firms: evidence from six European countries. ECORFAN Journal-Mexico. 2021. 12-26:1-9.

\footnotetext{
* Correspondence to Author (Email: oliver.lukason@ut.ee)

$\dagger$ Researcher contributing as first author.
} 


\section{Introduction}

Firm failure prediction is one of the main research areas in various literature streams, such as business, management, accounting and machine learning. Since the piloting multivariate study by Altman (1968), numerous prediction models have been composed and their amount is constantly growing. Financial ratios have been established as valuable predictors already fifty years ago and this fact has remained valid till today. Still, so far international comparative studies are scant in the failure prediction literature and only a few large-population intercountry studies are available (e.g. Laitinen and Suvas, 2013; Altman et al., 2017). While some sectors (e.g. manufacturing) have received considerable research attention, there is scant evidence available about others, such as transportation. The few published studies focusing on road transportation firms are singlecountry small-sample studies, and thus, a more generalized approach is needed.

Therefore, this paper aims to build an inter-country prediction model for road transportation firms. To justify the usefulness of the created model, its accuracy is being compared with single-country models based on the same input variables. In addition, the latter enables to draw a conclusion, whether the failure predictors of road transportation firms vary through countries and provide potential explanations to such variations. Thus, it is possible to contribute to the transportation management literature by outlining whether road transportation firms in different countries fail in the same way in the financial sense.

The paper is structured classically. The introductory part is followed by the review of literature, which focuses on the general achievements in the failure prediction literature as well as on transportation sector specific models. The data and method section describes the multi-country dataset used and the prediction method chosen. The results and discussion are consolidated into one section, which arguments over the results based on available knowledge from previous prediction models as well as provides a potential scientific explanation to the inter-country variation of prediction accuracies and predictors.
The study is summed up in the conclusive part, which also includes research limitations, implications and future research directions.

\section{Literature review}

Failure prediction studies have relied on a variety of definitions of failure (see for them e.g. Cochran, 1981), but dominantly studies narrow the definition to permanent insolvency or bankruptcy (Balcaen and Ooghe, 2006). The usage of bankruptcy as the definition has several benefits over a more broader definition such as earning losses, as the exact time of event is known and it is (often) final (Lukason and Laitinen, 2016). Still, some international studies have considered a broader definition, such as liquidation irrespective of whether insolvency occurred or not (Altman et al., 2017). Still, using insolvent and non-insolvent firms simultaneously in the population could not be a suitable option, as voluntary liquidation could also be characteristic to firms without any (remarkable) financial problems.

The multivariate bankruptcy prediction studies exploiting financial ratios as predictors have emerged from the piloting study by Altman (1968). When originally discriminant analysis was preferred as the method, since Ohlson (1980) logistic regression has gained popularity, mostly because it has less statistical restrictions. Nowadays, the area is methodologically developing mostly in the machine learning domain, where a myriad of different methods and algorithms have been introduced (Kumar and Ravi, 2007; du Jardin, 2017). Still, the classical statistical methods hold some advantage when compared with machine learning, as they enable more vividly to bring out the importance (significance) of included predictors. In turn, the machine learning methods mostly perform by using a "black box" logic, in case of which it might not be possible to show the individual importance of predictors, and derived from that, not to compare the importance of these predictors through different models (e.g. country-specific models). 
As predictor variables, financial ratios have been the most exploited in failure prediction research (e.g. Balcaen and Ooghe, 2006), while the application of non-financial variables (e.g. managerial characteristics, payment defaults, macroeconomic environment) remains in vast minority, probably because of data availability issues. Studies have reached varying results in respect to how valuable nonfinancial variables are in failure prediction, while there seems to be a consensus that they can provide at least some incremental value in combined models (Back, 2005; Ciampi, 2015; Iwanicz-Drozdowska et al., 2016).

Dozens of different financial ratios have been applied in failure prediction (Kumar and Ravi, 2007), although during the development of the research area since Altman (1968), certain variables have systematically performed better than others. Such variables mostly portray liquidity, solidity, profitability and leverage (Lukason et al., 2016), which were also included in the Altman (1968) study. Specifically, the Altman (1968) study included five variables: annual profitability, accumulated profitability, liquidity, leverage and productivity (asset turnover). Although the initial variables from Altman (1968) study have sustained their popularity, their coefficients have (largely) varied through sectors and countries (see e.g. the Altman et al. (2017) study incorporating millions of European firms from different sectors). In Altman et al. (2017), the assets' productivity was dropped because of its industry specificity, but in a single industry context that variable could still be useful.

The few available multi-country studies based on large samples (e.g. Laitinen and Suvas, 2013; Altman et al., 2017) have indicated that the usage of the same variables in different countries could lead to (largely) varying classification accuracies and importance of the variables. This phenomenon has been explained by the dominance of different failure processes in countries (Lukason et al., 2016; Lukason and Laitinen, 2019). Namely, when in some countries firms mostly decline quickly and shortly before bankruptcy, then in others the decline process is observable during a longer time frame (Lukason and Laitinen, 2019). The latter phenomenon could be explained by varying content and implementation of insolvency laws (Gutierrez et al., 2012).
Several studies about the failure prediction of transportation firms can be found in the literature, while attention has been mostly paid on airline industry (e.g. Chow and Gritta, 1988; Davalos et al., 1999; Gudmundsson, 1999; Lu et al., 2015). Other sectors, such as railroad (e.g. Altman, 1973), water (e.g. Lozinskaia et al., 2017) and land transportation (e.g. Balina and Juszczyk, 2014) have received considerably less research attention. The common features of the previous studies are that they are mostly single country studies with relatively small samples, thus reducing the universality of conclusions. Generally, these studies have applied (at least some of) the variables initially included in the Altman (1968) study and their significance in case of transportation firms has been proven.

Therefore, this study aims to find out, how useful are the financial ratios from Altman (1968) model in predicting the failure of road transportation firms in different European countries. The latter aim also incorporates composing country-specific models and comparing, whether the significance of financial ratios in prediction models varies through countries.

\section{Data and method}

The firm level data for this study originates from Bureau van Dijk Amadeus database, which includes financial information and statuses of firms from different European countries. Likewise with previous studies, firm is considered as failed, when it is insolvent. Therefore, firms with statuses "active insolvency proceedings" and "bankruptcy" are downloaded. Derived from the aim of the paper, only firms belonging to NACE Rev. 2 sector 4941 "Freight transport by roads" are considered. The preliminary screening of the failed firms' data reveals, that there are only six European countries, in case of which there are over 100 failed firms from the specific sector, in case of which all the necessary financial information is available. Thus, only these countries (Belgium, France, Hungary, Italy, Portugal, Romania) are kept in the analysis. Including countries with less than 100 observations makes the model's error from misclassifying a single failed company very large (i.e. $>1 \%$ ), and thus, it is not rational to include such countries. 
There are many options for obtaining the information about non-failed firms. The methodologically most correct is to choose firms with "active" status irrespective of how well they perform. Concerning the group of nonfailed firms, the most usual option in the literature has been to use a sample, often in (about) an equal size when compared with the failed ones. Thus, a random sample of active firms in these six countries is drawn from Amadeus database to match the size of the failed firms' sample. Also, an additional random sample of survived firms is downloaded from Amadeus to further check the robustness of the first random sample.

\begin{tabular}{|l|r|r|}
\hline Country & Test sample & Hold-out sample \\
\hline Belgium & 372 & 162 \\
\hline France & 2702 & 1158 \\
\hline Hungary & 306 & 132 \\
\hline Italy & 946 & 406 \\
\hline Portugal & 316 & 138 \\
\hline Romania & 794 & 342 \\
\hline Total & 5436 & 2338 \\
\hline
\end{tabular}

Table 1 Number of firms in test and hold-out samples by countries

Source: Own elaboration

The available observations are classically broken into two, where the first part represents the test sample for the model composition and the second part hold-out (control) sample for checking the model's performance. The test sample includes $70 \%$ of the available observations and the hold-out sample respectively $30 \%$. Table 1 tabulates the sample sizes by countries for the test and holdout samples, whereas in each country the sample divides equally in between failed and non-failed firms.

As variables, the five financial ratios applied in the piloting Altman (1968) study are used. As the literature review indicated, these financial ratios are theoretically motivated, cover all the main financial dimensions, and have been frequently used in prediction models (including examples from other subsectors of the transportation sector). The coding and formulas of these ratios have been presented in Table 2 . The failed firms' annual reports originate from years 2012-2016 and the same period is used to obtain annual reports for the non-failed firms. In case of failed firms, the annual report closest to one year before insolvency date is used.
The latter provides that failed firms are as homogenous as possible in respect to what preinsolvency period is viewed, as otherwise some reports might originate from a few months before insolvency and others several years before insolvency.

\begin{tabular}{|c|c|c|}
\hline Dimension & Code & Formula \\
\hline Liquidity & WCTA & $\begin{array}{l}\text { Working capital (i.e. } \\
\text { current assets - current } \\
\text { liabilities) / } \\
\text { total assets }\end{array}$ \\
\hline $\begin{array}{l}\text { Accumulated } \\
\text { profitability }\end{array}$ & RETA & $\begin{array}{l}\text { Retained earnings / } \\
\text { total assets }\end{array}$ \\
\hline $\begin{array}{l}\text { Annual } \\
\text { profitability }\end{array}$ & EBITTA & $\begin{array}{l}\text { EBIT / } \\
\text { total assets }\end{array}$ \\
\hline Leverage & BVETD & $\begin{array}{l}\text { Total equity / } \\
\text { total debt }\end{array}$ \\
\hline Productivity & OPRTA & $\begin{array}{l}\text { Operating revenue / } \\
\text { total assets }\end{array}$ \\
\hline
\end{tabular}

Table 2 Coding and formulas of financial ratios used in the analysis

Source: Own elaboration

As the method for prediction models' composition, the most widely used classical statistical analysis method for binary outcomes, i.e. logistic regression (LR), has been used. In LR, failed firms are coded with 1 and non-failed with 0 , which has been the usual coding in relevant studies. First, the inter-country LR model is composed. As countries have different frequencies in the analysis, likewise with Altman et al. (2017), the frequencies of countries have been equalized by weighting each country out of six by: (1/6)/(share of country's observations in the test sample). In this way, each of the countries obtains exactly the same importance in the analysis. An alternative would be not to weigh the cases by countries, but in that occasion the content of French observations would dominate in the analysis and it would not be possible to compose an inter-country model. After the composition of inter-country weighted LR model, it is applied on the hold-out sample to provide out of test sample validation. Before LR analysis, the variables are winsorized, as financial ratios can usually obtain abnormal values altering the coefficients in LR. 
In addition, after the composition of inter-country model, six separate country specific models are composed. In case of them, weighting is not important, as each model includes observations from a single country. Likewise with the inter-country model, each of them has been validated on the specific country's hold-out sample. This enables further comparison of the accuracies of a universal inter-country model and the separate countryspecific models. Also, the (in)significances of variables in the inter-country and countryspecific models are compared.

\section{Results and discussion}

First, the descriptive statistics of the applied five variables are outlined (see Table 3 ). The means of financial ratios through two groups indicate that failed and non-failed firms significantly differ in respect to liquidity, annual and accumulated profitability, leverage and productivity (see Table 3 notes section). While the means of all other ratios except for productivity also differ significantly through all studied countries, then in some countries (e.g. Portugal) the productivity ratio OPRTA does not differ. In addition, the means and medians indicate that the ratios have theoretically correct values. Namely, in respect to mean values before insolvency, failed firms indicate lower liquidity (current liabilities exceeding current assets), negative annual and accumulated profitability, excessive leverage and lower productivity. Therefore, already the descriptive analysis presented in Table 3 indicates the potential of these ratios to discriminate in between failed and non-failed firms.

The analysis is followed by presenting univariate prediction abilities of each of the financial ratios in the studied six countries separately and in the inter-country sample. The results in Table 4 are obtained by composing univariate LR models, and also, the ranking in each country is presented by providing the highest rank to the ratio enabling the best discrimination. The univariate prediction abilities remain on an average level, indicating that failed and non-failed firms are distinguishable, but not very precisely, when individual ratios are applied.

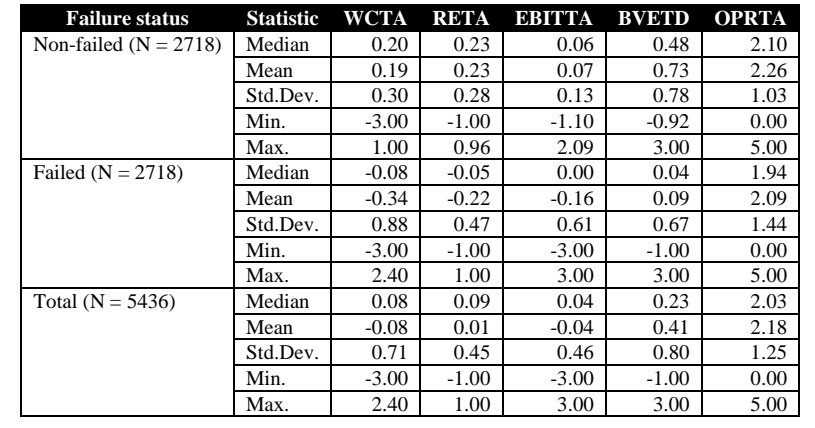

Note: Welch ANOVA test p-values $<0.0001$ when comparing the means of all five ratios in between two groups (failed and non-failed). When individual countries are considered, the Welch ANOVA test p-values $<0.0001$ for all ratios in all countries, except for OPRTA, which has p-value 0.013 in Hungary and 0.799 in Portugal.

Table 3 Descriptive statistics of financial ratios applied Source: Own elaboration

In line with the probabilistic theory of bankruptcy by Scott (1981), annual and accumulated profitability are the best predictors, although this result varies through countries. The liquidity and leverage ratios rank lower, which lends support to the finding in Lukason and Laitinen (2019) about the lesser usefulness of these variables in failure prediction when compared with profitability. Productivity clearly holds the last position among the rankings and due to low accuracies (resembling in many countries almost a "coin toss" situation), the individual usage of this variable in failure prediction is highly questionable. Indeed, this variable has been dropped from the modifications of Altman (1968) model, and thus, the result can be considered as expected.

\begin{tabular}{|l|r|r|r|r|r|}
\hline Ratio accuracy or rank \& country & WCTA & \multicolumn{1}{l}{ RETA } & \multicolumn{1}{c|}{ EBITTA } & BVETD & OPRTA \\
\hline RA Belgium & $61.6 \%$ & $67.2 \%$ & $60.8 \%$ & $60.5 \%$ & $62.1 \%$ \\
\hline RR Belgium & 3 & 1 & 4 & 5 & 2 \\
\hline RA France & $68.2 \%$ & $75.9 \%$ & $61.0 \%$ & $72.0 \%$ & $54.9 \%$ \\
\hline RR France & 3 & 1 & 4 & 2 & 5 \\
\hline RA Hungary & $71.6 \%$ & $77.1 \%$ & $72.9 \%$ & $70.3 \%$ & $57.5 \%$ \\
\hline RR Hungary & 3 & 1 & 2 & 4 & 5 \\
\hline RA Italy & $74.2 \%$ & $74.6 \%$ & $76.1 \%$ & $74.0 \%$ & $65.9 \%$ \\
\hline RR Italy & 3 & 2 & 1 & 4 & 5 \\
\hline RA Portugal & $71.5 \%$ & $70.9 \%$ & $72.2 \%$ & $71.2 \%$ & $52.5 \%$ \\
\hline RR Portugal & 2 & 4 & 1 & 3 & 5 \\
\hline RA Romania & $70.5 \%$ & $77.6 \%$ & $76.8 \%$ & $73.7 \%$ & $68.3 \%$ \\
\hline RR Romania & 4 & 1 & 2 & 3 & 5 \\
\hline Median RR & 3 & 1 & 2 & 4 & 5 \\
\hline
\end{tabular}

Note: RA - ratio accuracy. RR - ratio rank. The ratio ranks for five financial ratios are notified as: " 1 " - the ratio with highest univariate accuracy and " 5 " - the ratio with lowest univariate accuracy. The "median RR" is calculated as the median rank of six country ranks.

Table 4 Univariate accuracies of ratios in different countries and their ranking based on accuracies Source: Own elaboration 


\begin{tabular}{|l|r|r|r|r|}
\hline Variable & \multicolumn{1}{c}{ B } & \multicolumn{1}{c}{ S.E. } & \multicolumn{1}{l}{ Sig. } & \multicolumn{1}{c|}{$\operatorname{Exp}(\mathbf{B})$} \\
\hline WCTA & -0.577 & 0.056 & 0.000 & 0.562 \\
\hline RETA & -2.109 & 0.076 & 0.000 & 0.121 \\
\hline EBITTA & -0.753 & 0.072 & 0.000 & 0.471 \\
\hline BVETD & -0.130 & 0.033 & 0.000 & 0.878 \\
\hline OPRTA & -0.432 & 0.017 & 0.000 & 0.649 \\
\hline Constant & 0.901 & 0.040 & 0.000 & 2.461 \\
\hline
\end{tabular}

Note: Model R-squared 0.385. Mean variance inflation factor 2.19, indicating no issues with multicollinearity.

Table 5 Inter-country logistic regression failure prediction model

Source: Own elaboration

\begin{tabular}{|l|c|c|c|c|c|c|}
\multirow{2}{*}{ Country } & \multicolumn{3}{c}{ Test sample } & \multicolumn{3}{c|}{ Control sample } \\
\cline { 2 - 7 } & NF & \multicolumn{1}{c|}{ F } & \multicolumn{1}{c|}{ All } & \multicolumn{1}{c|}{ NF } & \multicolumn{1}{c|}{ F } & All \\
\hline Belgium & 72.0 & 67.7 & 69.9 & 67.9 & 75.3 & 71.6 \\
\hline France & 94.5 & 44.3 & 69.4 & 95.0 & 42.1 & 68.6 \\
\hline Hungary & 89.5 & 60.8 & 75.2 & 92.4 & 62.1 & 77.3 \\
\hline Italy & 79.5 & 84.4 & 81.9 & 74.9 & 80.8 & 77.8 \\
\hline Portugal & 70.3 & 77.8 & 74.1 & 69.6 & 69.6 & 69.6 \\
\hline Romania & 81.4 & 81.4 & 81.4 & 70.8 & 77.8 & 74.3 \\
\hline Mean & 81.2 & 69.4 & 75.3 & 78.4 & 68.0 & 73.2 \\
\hline
\end{tabular}

Note: NF - non-failed, F - failed.

Table 6 Inter-country logistic regression model accuracies in six countries' test and control samples (\%)

Source: Own elaboration

In Table 5, the results of an inter-country failure prediction model are presented, with model accuracies in Table 6. All applied five financial ratios are significant in predicting the future failure of firms, with coefficients having theoretically correct signs, i.e. the decrease in ratio value making failure more likely. The accuracy of the model on test and control sample remains on an average level, around a quarter of firms misclassified. The accuracy is higher for non-failed firms, while being modest in the failed firms' group. This indicates that many of the failed firms are not distinguishable from their non-failed counterparts and they probably follow an acute failure process, as proposed in Lukason and Laitinen (2019). The latter means that signs of future failure are not signaled through the annual reports available one year before failure and the critical events for these firms occur very shortly before insolvency emerges. Indeed, for the mostly SME population analyzed, such finding is not surprising, as in multiple previous studies such phenomenon has been documented (see e.g. Laitinen et al., 2014; Lukason et al., 2016).
There is around 10 percentage points variation in the accuracies through different countries, when the control sample is considered. In some countries (Belgium, Italy, Portugal, Romania) the accuracies for failed and non-failed firms are quite similar, while in others (France, Hungary) there is a substantial difference in favor of the non-failed group. Portuguese and Italian test samples are the only ones in which the accuary for failed firms exceeds that of non-failed.

\begin{tabular}{|l|c|c|c|c|c|c|}
\hline \multicolumn{1}{c}{ Country } & \multicolumn{3}{c}{ Test sample } & \multicolumn{3}{c|}{ Control sample } \\
& \multicolumn{1}{c}{ NF } & \multicolumn{1}{c}{ F } & \multicolumn{1}{c|}{ All } & \multicolumn{1}{c|}{ NF } & F & All \\
\hline Belgium & 76.9 & 68.8 & 72.8 & 70.4 & 75.3 & 72.8 \\
\hline France & 79.6 & 72.8 & 76.2 & 74.8 & 72.9 & 73.8 \\
\hline Hungary & 86.9 & 66.0 & 76.5 & 95.5 & 72.7 & 84.1 \\
\hline Italy & 86.5 & 79.9 & 83.2 & 84.2 & 76.8 & 80.5 \\
\hline Portugal & 79.7 & 72.8 & 76.3 & 78.3 & 60.9 & 69.6 \\
\hline Romania & 86.9 & 80.9 & 83.9 & 76.0 & 73.7 & 74.9 \\
\hline
\end{tabular}

Note: NF - non-failed, F - failed.

Table 7 Country-specific logistic regression models' accuracies in six countries' test and control samples (\%) Source: Own elaboration

The country-specific LR models documented in Table 7 indicate that in several countries (France, Hungary, Italy) the composition of a country-specific model leads to a few percentage points higher accuracy in classification, while in others (Belgium, Portugal, Romania) the accuracies are quite similar to Table 6. Therefore, failed road transportation firms in different countries are somewhat different, but not substantially, the latter justifying the usage of a universal model.

\begin{tabular}{|l|l|l|l|l|l|}
\hline \multicolumn{1}{c|}{ Country } & \multicolumn{2}{|c}{ WCTA } & \multicolumn{1}{c}{ RETA } & \multicolumn{1}{c|}{ EBITTA } & \multicolumn{2}{c|}{ BVETD } & OPRTA \\
\hline Belgium & & + & & & + \\
\hline France & & + & + & & + \\
\hline Hungary & & + & & & \\
\hline Italy & + & + & + & + & + \\
\hline Portugal & + & + & & & + \\
\hline Romania & + & + & + & & + \\
\hline
\end{tabular}

Note: "+" indicates that the specific financial ratio is significant at $\mathrm{p}<0.05$ in the country-specific model.

Table 8 Variables significant in country-specific models Source: Own elaboration 
The variables significant in countryspecific models documented in Table 8 provide insights to the failure processes the transportation firms in these countries follow. In all countries, accumulated profitability (RETA) and productivity (OPRTA; except for Hungary) are significant predictors. Thus, some proportion of firms in all countries have lost their competitive advantage and probably witnessed multiple consecutive years of negative profitability. Such firm type has been proposed in previous studies, for instance as "lingerers" in D'Aveni (1989) or "apathetic firms" in Ooghe and de Prijcker (2008). The latter firms could have been liquidated (long) before the start of insolvency proceedings and probably the legislative framework of resolving insolvencies does not guarantee speedy elimination of inefficient firms from the market. Annual profitability (EBITTA) and liquidity (WCTA) are significant predictors in half of the countries, while leverage (BVETD) only in one country. Based on Laitinen's (1995) concept of different bankruptcy processes, road transportation firms from Belgium, France and Hungary seem to be subject to solidity problems only one year before failure, while in Italy, Portugal and Romania, liquidity and solidity problems both seem to matter.

For comparative purposes, we used the most robust international prediction model by Altman et al. (2017), which includes all the financial ratios applied in this study except for OPRTA. Namely, when using the second model from that study, the following accuracies are obtained: Belgium $63.5 \%$, France $70.0 \%$, Hungary $78.8 \%$, Italy $75.5 \%$, Portugal $71.7 \%$, Romania $70.2 \%$. The accuracies mostly remain lower when compared with the ones obtained in this study (see Table 6 and 7). Thus, peculiarities of the transportation sector play a certain role and a multi-country multi-sector model is not as useful as a sector-specific in predicting the demise of firms. Also, when an additional nonfailed firms' sample is used, then the significant variables in Tables 5 and 8 are not altered, and thus, there is no non-failed firms' sample selection bias in the study. The latter is not an issue for failed firms, as available whole population was applied.

\section{Conclusion}

This paper aimed to create an inter-country failure prediction model for road transportation firms from different European countries. All failed (i.e. bankrupted) road transportation firms from six European countries and comparative sample of non-failed (i.e. survived) firms from the same countries were applied. As variables, five financial ratios originating from Altman (1968) study, and as the method, logistic regression were applied.

The results indicate that all five financial ratios from Altman (1968) study are significant predictors of road transportation firms' failure. The accuracy of the prediction model (for both, test and hold-out sample) can vary through countries. The country-specific prediction models have similar accuracies as the intercountry model, although the significances of specific predictors can vary through countries.

As a practical implication, credit analysts can account that failure of road transportation firms is predictable with an average accuracy with classical financial ratios and logistic regression analysis. Thus, for many firms from this sector, problems can arise shortly before bankruptcy is declared and variables other than financial ratios are needed to enhance prediction accuracies.

The paper can be developed further by using a larger population of European countries, a longer time horizon of financial performance before bankruptcy is declared, or variables other than financial ratios. Concerning the latter, managerial characteristics or payment defaults could be beneficial. In addition, the usage of a longer time horizon and more diversified variables would enable to test a complex theory of why and how road transportation firms fail.

\section{Acknowledgement}

We acknowledge financial support Estonian Research Council's grant PRG791 "Innovation Complementarities and Productivity Growth" and the Estonian Research Infrastructures Roadmap project "Infotechnological Mobility Observatory (IMO)". 


\section{References}

Altman, E.I. (1968). Financial ratios, discriminant analysis and the prediction of corporate bankruptcy. Journal of Finance, 23(4), 589-609.

Altman, E.I. (1973). Predicting railroad bankruptcies in America. The Bell Journal of Economics and Management Science, 4(1), 184211.

Altman, E.I., Iwanicz-Drozdowska, M., Laitinen, E.K., \& Suvas, A. (2017). Financial distress prediction in an international context: A review and empirical analysis of Altman's ZScore model. Journal of International Financial Management \& Accounting, 28(2), 131-171.

Back, P. (2005). Explaining financial difficulties based on previous payment behaviour, management background variables and financial ratios. European Accounting Review, 14(4), 839868.

Balcaen, S., \& Ooghe, H. (2006). 35 years of studies on business failure: An overview of classic statistical methodologies and their related problems. The British Accounting Review, 38(1), 63-93.

Balina, R., \& Juszczyk, S. (2014). Forecasting bankruptcy risk of international commercial road transport companies. International Journal of Management and Enterprise Development, 13(1), 1-20.

Chow, G., \& Gritta, R.D. (1988). Estimating bankruptcy risks facing class I and II motor carriers: An industry-specific approach. Transportation Practitioners Journal, 55(4), 352-363.

Ciampi, F. (2015). Corporate governance characteristics and default prediction modeling for small enterprises. An empirical analysis of Italian firms. Journal of Business Research. 68(5), 1012-1025.

Cochran, A.B. (1981). Small business mortality rates: a review of the literature. Journal of Small Business Management, 19(4), 50-59.
D'Aveni, R. (1989). The aftermath of organizational decline: a longitudinal study of the strategic and managerial characteristics of declining firms. Academy of Management Journal, 32(3), 577-605.

Davalos, S., Gritta, R.D., \& Chow, G. (1999). The application of a neural network approach to predicting bankruptcy risks facing the major US air carriers: 1979-1996. Journal of Air Transport Management, 5(2), 81-86.

du Jardin, P. (2017). Dynamics of firm financial evolution and bankruptcy prediction. Expert Systems with Applications, 75, 25-43

Gudmundsson, S.V. (1999). Airline failure and distress prediction: a comparison of quantitative and qualitative models. Transportation Research Part E: Logistics and Transportation Review, 35(3), 155-182.

Gutiérrez, C.L., Olmo, B.T., \& Azofra, S.S. (2012). Firms' performance under different bankruptcy systems: a Europe-USA empirical analysis. Accounting \& Finance, 52(3), 849-872.

Iwanicz-Drozdowska, M., Laitinen, E.K., Suvas, A., \& Altman, E.I. (2016). Financial and nonfinancial variables as long-horizon predictors of bankruptcy. Journal of Credit Risk, 12(4), 49-78.

Kumar, P.R., \& Ravi, V. (2007). Bankruptcy prediction in banks and firms via statistical and intelligent techniques - A review. European Journal of Operational Research, 180(1), 1-28.

Laitinen, E.K. (1995). The duality of bankruptcy process in Finland. European Accounting Review, 4(3), 433-454.

Laitinen, E.K., \& Suvas, A. (2013). International applicability of corporate failure risk models based on financial statement information: Comparisons across European Countries. Journal of Finance \& Economics, 1(3), 1-26.

Laitinen, E.K., Lukason, O., \& Suvas, A. (2014). Are firm failure processes different? Evidence from seven countries. Investment Management and Financial Innovations, 11(4), 212-222. 
Lozinskaia, A., Merikas, A., Merika, A., \& Penikas, H. (2017). Determinants of the probability of default: the case of the internationally listed shipping corporations. Maritime Policy \& Management, 44(7), 837858.

Lu, C., Yang, A.S., \& Huang, J.-F. (2015). Bankruptcy predictions for U.S. air carrier operations: a study of financial data. Journal of Economics and Finance, 39(3), 574-589.

Lukason, O., \& Laitinen, E.K. (2016). Failure processes of old manufacturing firms in different European countries. Investment Management and Financial Innovations, 13(2), 310-321

Lukason, O., \& Laitinen, E.K. (2019). Firm failure processes and components of failure risk. Journal of Business Research, 98, 380-390.

Lukason, O., Laitinen, E.K., \& Suvas, A. (2016). Failure processes of young manufacturing micro firms in Europe. Management Decision, 54(8), 1966-1985.

Ohlson, J.A. (1980). Financial ratios and the probabilistic prediction of bankruptcy. Journal of Accounting Research, 18 (1), 109-131.

Ooghe, H., \& de Prijcker, S. (2008). Failure processes and causes of company bankruptcy: a typology. Management Decision, 46(2), 223242.

Scott, J. (1981). The probability of bankruptcy: A comparison of empirical predictions and theoretical models. Journal of Banking \& Finance, 5(3), 317-344. 